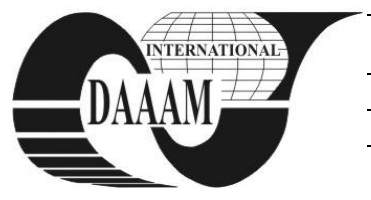

\title{
DEVELOPMENT OF NEW PRODUCT IN THE FUZZY FRONT END STAGE WITH MULTI-CRITERIA APPROACH
}

\author{
KOSTANJEVEC, T[omaz]
}

\begin{abstract}
Variety of different approaches presented in article can organizations use for finding new methods to efficiently serve existing and new markets. The turbulent global environment is compelling organizations to constantly seek for the most efficient models to maximize their innovation management efforts. As product development (PD) is a responsibility of all departments, their involvement needs to be determined accordingly. An organization's ability to identify, acquire, and utilize external ideas can be seen as a critical factor in regards of its market success.

The multi-criteria $(M C)$ product development tool is in article presented as an effective and useful tool in the "fuzzy front end stage" of planning the development of a new product.

Key words: product development, multi-criteria approach, fuzzy front end
\end{abstract}

\section{INTRODUCTION}

The early stages of the new product development process are most often defined as idea generation, idea screening, concept development and concept testing. These stages represent the development of an idea prior to its taking any physical form. In most industries it is from this point onwards that costs will rise significantly. It is clearly far easier to change a concept than a physical product.

The term "fuzzy front end" describes the earliest stage of an idea development and includes all the time spent on an idea as well as activities focusing on strengthening this idea, prior to the first official discussion of the idea. The origin for ideas is both internal and external sources (von Hippel, 1988). The differences to the new product and process development are important to consider. During the application of the methodology, the number of ideas - originally in the form of futuristic projections and innovation potentials and then in detailed product concepts - is constantly being reduced. This reduction in the number of ideas through the so called idea funnel is necessary as the required work content is increasing as the ideas are becoming more and more concrete - there is a reduction in flexibility and agility available per idea.

The route from idea generation untill idea realisation is summarized in Fig. 1. The MC method used is mapped and modified according to this relationship between concreteness of an idea and number of ideas. This means that the more concrete the formulation of an idea - depending on the stage within the planning timeframe - the more detailed and specific the relevant methods used become. The presented article shows the possibility of using MC method in "fuzzy front end" stage. The company which developed a new product can, in the initial phase of choosing the most appropriate one on the base of MC analysis, seek the most suitable. The ability of MC analysis is to articulate the idea on the base of company abilities and market demands. Companies cannot eliminate the need for the new product forecast; especially during the commercialisation stage (prelaunch) where the new product forecast drives a variety of multifunctional decisions.

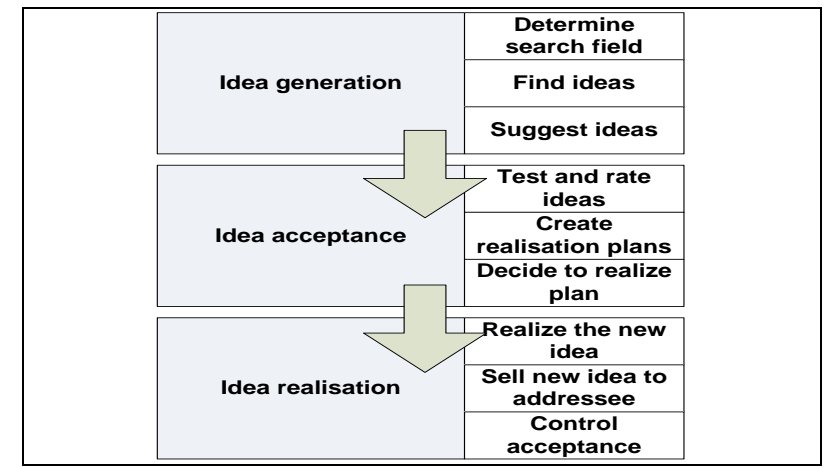

Fig. 1. Successive choice or elimination of ideas and refining

\section{FUZZY FRONT END OF INNOVATION WITH HELP OF MC APPROACH}

Terms "fuzzy front end" and front end innovation are treated similary. The expression of fuzziness implies an innovation process phase consisting of unknowable and uncontrollable factors (Koen et al., 2001). In this context, this phase is similar to the introduced idea generation stage but the focus on the front end is mainly on opportunity identification and analysis. Therefore, the front end is one of the greatest areas of weakness of the innovation process and fundamentally determines the later innovation success. Management of the front end results in a sustainable competitive innovation advantage.

A flow-oriented approach, the "idea tunnel", which resulted from an older concept called "development funnel" (Hayes et al., 1988), is the elementary basic model for front end considerations. There are two alternative ways of gaining ideas: collecting ideas in the sense that the ideas are already present somehow, at least in the mind of a person or a group. Creation is considered as a well thought-out generation of ideas through creativity methods. Creativity practice methods and techniques are needed to create a continuous spirit of creative evolution. Key elements for promoting corporate creativity are a motivating reward system, officially recognized creativity initiatives, the encouragement of self-initiated activities as well as the possibility of redundancy.

Several general requirements must be fulfilled in order to generate ideas that will be successful in the marketplace (Boeddrich, 2004):

- Considering the company's corporate strategy

- Obvious benefits for the ideas' target audience

- Systematically structured and conducted concept identification phase

There are not only general but also company-specific ramifications to consider which increase the complexity (Boeddrich, 2004). That is why there is always a dilemma between giving the front end a certain system and structure on the one hand and forcing creativity as well as implementing externals on the other hand. 
The most popular "fuzzy front end" is the new concept development model (Koen et al., 2001), which is supposed to provide a common language for front end activities. The circular shape shows the flow, circulation, and iteration of ideas within the five core elements and the surrounding external influencing factors. A fundamental distinction is made between an opportunity and an idea. Thus, the opportunity identification and analysis precedes an (business) idea because these stages include an ongoing process of several information enrichment stages like market studies or scientific experiments. A formal business plan or project proposal finally indicates the changeover to the new product and process development.

There is a specific differentiation between single process steps on the one hand and organizational responsibilities on the other. Boeddrich (2004) identified company-specific preconditions for the successful management of front end activities, confirmed by several other studies:

- definition of company-specific idea categories,

- commitment to company-specific evaluation methods and selection criteria with commitment to the owner of the idea management process,

- commitment to individuals or organizational units that promote innovation within the company,

- definition of creative scopes for the company,

- influence of the top management and investigation of stakeholders' participation,

- number of stages and gates in the tailor-made idea management.

\begin{tabular}{|c|c|c|c|c|c|}
\hline $\begin{array}{c}\text { Strategic } \\
\text { guidelines } \\
\text { for } \\
\text { innovations }\end{array}$ & \begin{tabular}{|c|} 
Idea \\
gener- \\
ation and \\
adoption
\end{tabular} & \begin{tabular}{|c|} 
Idea screening, \\
execution and further \\
conceptual \\
development \\
\end{tabular} & $\begin{array}{c}\text { Preliminary } \\
\text { projects }\end{array}$ & \multirow{2}{*}{$\mid \begin{array}{l}5 \\
\frac{0}{3} \\
\frac{2}{0} \\
0 \\
0\end{array}$} & $\begin{array}{l}\text { Portfolio of } \\
\text { innovation } \\
\text { projects }\end{array}$ \\
\hline \multicolumn{4}{|c|}{$\begin{array}{c}\text { Idea management, concept finding phase, - } \\
\text { predevelopment phase }\end{array}$} & & $\begin{array}{c}\text { Project } \\
\text { management }\end{array}$ \\
\hline $\begin{array}{c}\text { Development } \\
\text { of innovation } \\
\text { guidelines by } \\
\text { top } \\
\text { management } \\
\text { and } \\
\text { innovation } \\
\text { manager }\end{array}$ & \begin{tabular}{|} 
Strategic \\
analysis \\
of ideas \\
by idea \\
or inno- \\
vation \\
manager
\end{tabular} & $\begin{array}{l}\text { Cross-functional } \\
\text { teams reach } \\
\text { decisions on ideas } \\
\text { based on estimation } \\
\text { (product, technical, } \\
\text { financial, and market } \\
\text { attractiveness) }\end{array}$ & $\begin{array}{c}\text { Verification } \\
\text { of } \\
\text { estimations }\end{array}$ & & $\begin{array}{l}\text { Multi- project- } \\
\text { management } \\
\text { Allocation of } \\
\text { R\&D-budget }\end{array}$ \\
\hline
\end{tabular}

Tab. 1. Front end model proposal (Boeddrich, 2004)

The idea about MC analysis of product acceptability in the market was developed from observing two-dimensional graphs showing the dependence of the dependent variable from the independent one. The independent variable represents time, the dependent one is derived from the observed and most representative parameters (Kostanjevec et al., 2008).

The analysis and collection of trends is a continual process used in the early clarification (Trott, 2008). A trend can be described as the basic direction of either a development or a development bias. The "trend scanning" takes place in different observation areas, which together form the observation field. It represents the global environment of the formation field. In the ideal case, detailed information on developments in single observation areas already exist in the business so that these can be analyzed formation field-specifically. If the trend-scanning in a business is established, a list of trends from the various observation areas exists, that is reviewed, permanently updated and analyzed regarding its relevance. In addition to the available trends, the observation areas can be examined formation field-specific. Obviously, a complete analysis of the collection of trends is required. In Fig. 2, a multi-dimensional graph is displayed, in which each product parameter has its own dimension and polarity defined. The movement of data for each parameter is independent of other parameters but they all describe a single product. For this reason, the common centre of gravity is a generic indicator of the movement of production parameters for the evaluated product.

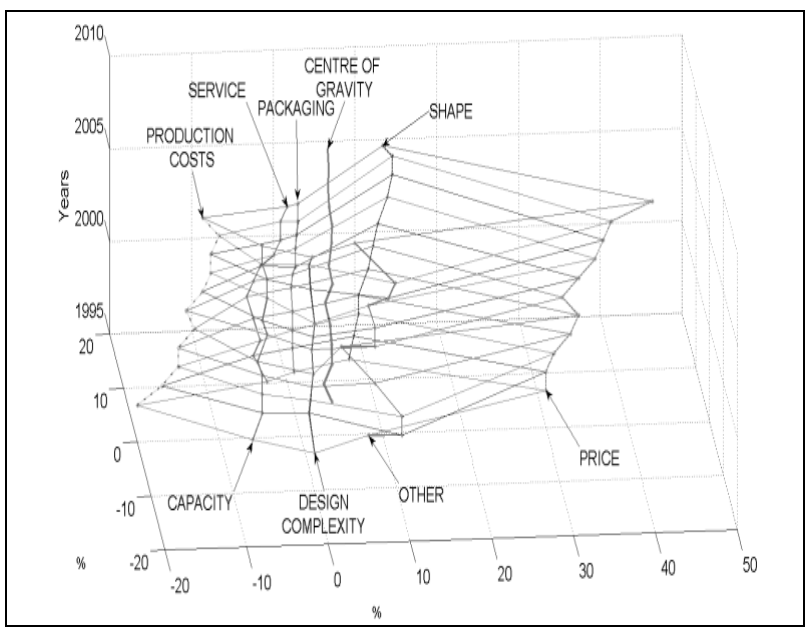

Fig. 2. 3D model with the addition of the centre of gravity as a possible trend (Kostanjevec et al, 2008)

\section{CONCLUSION}

It can be summarized that the described model of MC analysis can be a possibility for PD in "fuzzy front end" stage. MC approach is a powerful tool in terms of perception, resources considerations and detailing with appropriate data support. Both concepts ("fuzzy front end" and MC) have in common that they are based on empirical research, especially case studies. Hence, even across different companies, industries and strategies of product and process development, the front end innovation challenges and threats seem to be very similar. Still, more interbranch-based research is needed for further considerations.

Future product developments can be predicted independently from the current production boundaries. This gives the development much more flexibility. Reliable trends for the most important product parameters are evident from market demands.

An alternative form of PD can be based on the simple idea that a product at a given time is of combined from various parameters (Kostanjevec et al., 2008). With the powerful tool of $\mathrm{MC}$ analysis, investors can correctly forecast PD in an early phase of idea creation.

\section{REFERENCES}

Boeddrich, H. - J., (2004). Ideas in the work place: a new approach towards organizing the fuzzy front end of the innovation process. Creativity \& innovation management, 13, 4, 274 - 285, ISSN 1467-8691

Hayes, R. H., Wheelwright, S. C. \& Clark, K. B., (1988). Dynamic manufacturing: creating the learning organization. Free Press, ISBN 0029142113, New York

Koen, p. (et al), (2001). Providing clarity and a common language to the "fuzzy front end". Research technology management, 44, 2, 46-55, ISSN 08956308

Kostanjevec, T.; Polajnar, A. \& Vujica-Herzog, N. (2008). Product development through multi-criteria analysis. Annals of Daaam for 2008 proceedings of the $19^{\text {th }}$ International DAAAM Symposium "Intelligent manufacturing \& Automation: "Focus on next generation of intelligent systems and solutions", Katalinić, B. (Ed.), pp. 723-724, ISBN 978-3-301509-68-1, Vienna

von Hippel, E., (1988). The sources of innovation. Oxford University Press, ISBN 0-19-504085-6, New York

Trott, P. (2008) Innovation management and new product development. $4^{\text {th }}$ ed. Prentice Hall, ISBN 10 0-07-7114159, London 